\title{
COVID-19 Disease and Vitamin D: A Mini-Review
}

\author{
Mohamed Said Boulkrane ${ }^{1}$, Victoria llina ${ }^{1}$, Roman Melchakov ${ }^{1}$, Julia Fedotova ${ }^{2,3 *}$, \\ Filippo Drago ${ }^{4}$, Lucia Gozzo ${ }^{4}$, Undurti Narasimha Das ${ }^{5}$, A. M. Abd El-Aty ${ }^{6,7}$ and \\ Denis Baranenko ${ }^{1}$
}

${ }^{1}$ International Research Centre "Biotechnologies of the Third Millennium", ITMO University, Saint-Petersburg, Russia, ${ }^{2}$ Laboratory of Neuroendocrinology, I.P. Pavlov Institute of Physiology, Russian Academy of Sciences, St. Petersburg, Russia, ${ }^{3}$ Lobachevsky State University of Nizhny Novgorod, Nizhny Novgorod, Russia, ${ }^{4}$ Department of Biomedical and Biotechnological Sciences, Biological Tower, School of Medicine, University of Catania, Catania, Italy, ${ }^{5}$ UND Life Sciences, Battle Ground, WA, United States, ${ }^{6}$ Department of Pharmacology, Faculty of Veterinary Medicine, Cairo University, Giza, Egypt, ${ }^{7}$ Department of Medical Pharmacology, Medical Faculty, Ataturk University, Erzurum, Turkey

Novel coronavirus disease (COVID-19) pandemic caused by SARS-CoV-2, for which there is no effective treatment except employing prevention strategies, has already instituted significant number of deaths. In this review, we provide a scientific view on the potential role of vitamin D in SARS-CoV-2 virus/COVID-19 disease. Vitamin D is well-known to play a significant role in maintaining the immune health of an individual. Moreover, it induces antimicrobial peptide expression that can decrease viral replication and regulate the levels of pro-inflammatory/anti-inflammatory cytokines. Therefore, supplementation of vitamin D has the potential to reduce the incidence, severity and the risk of death from pneumonia resulting from the cytokine storm of many viral infections including COVID-19. We suggest that supplementation of subjects at high risk of COVID-19 with vitamin D (1.000 to 3.000 IU) to maintain its optimum serum concentrations may be of significant benefit for both in the prevention and treatment of the COVID-19.

Keywords: SARS-CoV-2, COVID 19, respiratory tract infection, vitamin D3, vitamin D3 receptor

\section{INTRODUCTION}

The occurrence of respiratory tract infections (RTI) is more common in winter, especially in the northern regions, than in the summer months (Hope-Simpson, 1981). This also applies to the rapidly spreading in the winter period around the world of the infectious Coronavirus disease 2019 (COVID19) which became a pandemic, since the virus is more easily transmitted at low temperatures $(\mathrm{Qu}$ et al., 2020; Sajadi et al., 2020). This rises the possibility that insufficient intake of vitamin $\mathrm{D}_{3}$ may have a role in the development and severity of COVID-19. Thus, in order to curb the current pandemic of COVID-19, it is opined that the administration of an adequate amounts of vitamin $\mathrm{D}_{3}$ may stem the current situation till an effective therapy, chemoprophylaxis, and vaccination is developed.

Deficiency of vitamin $\mathrm{D}_{3}$ in all age groups is a public health problem (Palacios and Gonzalez, 2014) that is well recognized. It is estimated that more than one billion people suffer from vitamin $D_{3}$ deficiency (Van Schoor and Lips, 2011). Several previous studies suggested that there is an independent association between low plasma concentrations of 25-hydroxyvitamin $\mathrm{D}_{3}$ and susceptibility to acute respiratory infections (Cannell et al., 2006). Vitamin $\mathrm{D}_{3}$ deficiency has been associated with many diseases including but not limited to type 2 diabetes mellitus, heart disease, stroke, autoimmune diseases, asthma and RTIs (Hollick, 2007; Hollick, 2017). The relation 
between low levels of vitamin $\mathrm{D}_{3}$ and infection with bovine diarrhea virus in calves has been well established (Nonnecke et al., 2014). It is evident that in winter due to the shorter time spent in the sun, the plasma levels of vitamin $\mathrm{D}_{3}$ is likely to be low (Berardi and Newton, 2009; https://www.medlineplus.gov/ vitamind.html). This is especially evident in countries such as the United States of America (USA), United Kingdom (UK), Switzerland, Italy, Spain, Iran, France, Turkey, etc. It is rather interesting that COVID-19 pandemic and its high mortality (Pharmacy Times, 2020; https:/www.pharmacytimes.com/ publications/issue/2010/february2010/otcfocusvitamind-0210) has been reported in these countries. According to the US National Center for Health Statistics, approximately $70 \%$ of the population may be deficient in vitamin $\mathrm{D}_{3}$ and surprisingly while the United States is presently the most affected by COVID-19 (Kmiec et al., 2014). This is in line with the current proposal that severe acute respiratory syndrome due to SARS-CoV-2 and its associated high mortality rate may be as a result of vitamin $\mathrm{D}_{3}$ deficiency. Furthermore, vitamin $\mathrm{D}_{3}$ deficiency is known to elevate with increasing age and comorbidities that are associated with lower vitamin $\mathrm{D}_{3}$ levels.

In the current review, we present a scientific rationale on the potential relationship between vitamin $\mathrm{D}_{3}$ content and higher incidence of Severe Acute Respiratory Syndrome Coronavirus-2 (SARS-CoV-2) virus infection. Moreover, our review also summarizes the current understanding of the link among vitamin $\mathrm{D}_{3}$, the immune system, and respiratory infections.

\section{VITAMIN D AND IMMUNE SYSTEM}

Vitamin D is a pluripotent hormone that modulates the innate and adaptive immune responses (Rezaei, 2018). Vitamin D could play a decisive role in the proliferation and immunomodulation of cells, affecting several immune pathways enhancing the protective properties of the mucous membranes of the body and inhibiting excessive inflammation (D'Ambrosio et al., 1998; Khare et al., 2013; Parlak et al., 2015). Immunocytes such as macrophages, $\mathrm{B}$ and $\mathrm{T}$ lymphocytes, neutrophils and dendritic cells express Vitamin $\mathrm{D}_{3}$ receptors (VDRs) that is enable to the actions of vitamin D (Di Rosa et al., 2011). The active metabolite of vitamin D lead to the activation of VDRs that can form Retinoid X Receptor (RXR) heterodimer that, in turn, influences the proteins of the innate and adaptive immune system (the regulatory $\mathrm{T}$ cells, defensins, cytokines, pattern recognition receptors, etc.) (Chun et al., 2014).

The immune system is influenced in various ways by both vitamin $\mathrm{D}_{3}$ and its metabolite 1,25-hydroxy-vitamin $\mathrm{D}_{3}$. 1,25hydroxy-vitamin $\mathrm{D}_{3}$ rigorously regulates antimicrobial peptides such as defensin and cathelicidin (Adams et al., 2009). Cathelicidin possesses an antimicrobial function against mycobacteria, Gram-positive and Gram-negative bacteria due to its ability to destroy cell membranes. 1,25-hydroxy-vitamin $\mathrm{D}_{3}$ has antiviral effect against adenovirus, herpes simplex virus, enveloped and non-enveloped retroviruses, and fungi (Herr et al., 2007). By damaging cell membranes, these peptides penetrate infected cells and neutralize the action of endotoxins (Agier et al., 2015). For instance, the LL-37, antimicrobe peptide, has antibacterial and antifungal properties by virtue of its ability to disrupt the integrity of the cell membrane and proton gradient (Bals and Wilson, 2003) by vitamin $\mathrm{D}_{3}$ (Howell et al., 2004; Leikina et al., 2005; Steinstraesser et al., 2005; Bergman et al., 2007). In addition, vitamin $D_{3}$ inhibits the production of proinflammatory cytokines and augments that of anti-inflammatory cytokines (Gombart et al., 2020). Thus, vitamin $\mathrm{D}_{3}$ influences the incidence and severity of viral infections by altering the production of pro-inflammatory cytokines. There is reasonable evidence to suggest that vitamin $\mathrm{D}_{3}$ can inhibit the transcription induced by tumor-necrosis-factor- $\alpha$ (TNF- $\alpha)$ in latently infected cells by human immunodeficiency viruses (HIV) (Nunnari et al., 2016). These and other results suggest that vitamin $D_{3}$ can inhibit the production of inflammatory cytokines and chemokines such as TNF- $\alpha$, interferon- $\beta$ (IFN- $\beta$ ), interleukine (IL)-8, IL-6 and Regulated upon Activation, Normal $\mathrm{T}$ Cell Expressed and Presumably Secreted (RANTES) (Hansdottir et al., 2010; Khare et al., 2013). Increase in mortality in those with COVID-19 is due to acute respiratory distress syndrome (ARDS) due to unantagonized production of proinflammatory cytokines IL-6 and TNF- $\alpha$. Vitamin $\mathrm{D}_{3}$ has a decisive role in the regulation of the innate and adaptive immune responses implying that adequate intake of vitamin $\mathrm{D}_{3}$ may protect patients with COVID-19 at least, in part by inhibiting the excess production of IL- 6 and TNF- $\alpha$ (Daneshkhah et al., 2020). Vitamin $\mathrm{D}_{3}$ can also contribute to the modification of the antiviral response by enhancing the secretion of pro-inflammatory chemokines (C-X-C Motif Chemokine Ligand 8, CXCL8 and C-X-C Motif Chemokine Ligand 10, CXCL10) (Brockman-Schneider et al., 2014). Lytic phase of cytomegalovirus (CMV) replication can be induced by vitamin $\mathrm{D}_{3}$ in vitro (Wu and Miller, 2015).

Vitamin $\mathrm{D}_{3}$ promotes immunoglobulin and complementmediated phagocytosis by stimulating the maturation of monocytes to macrophages. In addition, vitamin $\mathrm{D}_{3}$ maintains self-tolerance by reducing a hyperactive adaptive immune system (Bowie and Unterholzner, 2008). Vitamin $\mathrm{D}_{3}$ reduces the replication of influenza A (Barlow et al., 2011), rotavirus (Zhao et al., 2019) and dengue microbes (Martínez-Moreno et al., 2019). These results imply that excess innate immune response induced by viral and other microbial infections seen in patients with SARS-CoV-2 and associated cytokine storm can be effectively reduced by vitamin $\mathrm{D}_{3}$ (Huang et al., 2020). The immunomodulatory effect of vitamin $\mathrm{D}_{3}$ on viral infections appears to be temporary and at least, this in part could be attributed to its immunomodulatory role in viral infections is rather complex and depends on the nature of the pathogen and the type of immune function that is needed to resolve the disease process (Sacco et al.,2012; Gotlieb et al., 2018).

There is reasonable evidence to suggest that vitamin $\mathrm{D}_{3}$ modulates adaptive immune responses by inhibiting the Th1 cell function that leads to a reduction in the production of TNF- $\alpha$, IL-2, granulocyte macrophage colony-stimulating factor and IFN- $\beta$. $1,25-(\mathrm{OH})_{2}$-Vitamin $\mathrm{D}_{3}$ enhances the action of Th2 cells and production of their anti-inflammatory cytokines, IL- 
TABLE 1 | Some effects of vitamin D on the immune system.

\begin{tabular}{|c|c|c|}
\hline Immune cell type & Effect of vitamin D & References \\
\hline Airway epithelium & $\begin{array}{l}\text { Increases CD14 and cathelicidin. Dampens IFN- } \beta \text { and chemokine response } \\
\text { during viral infection }\end{array}$ & Hansdottir et al. (2010) \\
\hline $\begin{array}{l}\text { Alveolar } \\
\text { macrophages }\end{array}$ & Increases the antimicrobial peptide cathelicidin & Liu et al. (2007) \\
\hline Dendritic cells & $\begin{array}{l}\text { Inhibits dendritic cell differentiation, maturation and function, decreases IL- } \\
12 \text { and increases IL-10, alters T cell activation }\end{array}$ & $\begin{array}{l}\text { Penna and Adorini (2000); Piemonti et al. (2000); Fritsche et al. (2003); } \\
\text { Sigmundsdottir et al. (2007) }\end{array}$ \\
\hline T lymphocytes & $\begin{array}{l}\text { Inhibits proliferation, modulates cytokine production - inhibits Th1 and Th17 } \\
\text { cytokines but induces Tregs }\end{array}$ & $\begin{array}{l}\text { Lemire et al. (1995); Penna and Adorini (2000); Sigmundsdottir et al. } \\
\text { (2007); Daniel et al. (2008); Mora et al. (2008) }\end{array}$ \\
\hline B lymphocytes & Inhibits proliferation of activated B cells and generation of plasma cells & Chen et al. (2007) \\
\hline
\end{tabular}

4, IL-5, and IL-10 (Hughes and Norton, 2009). In addition, supplementation of vitamin $\mathrm{D}_{3}$ increases the number of regulatory $\mathrm{T}$ cells (Treg cells), suppresses IgG production and differentiation of dendritic cells (Kamen and Tangpricha, 2010; Aranow, 2011; Rondanelli et al., 2018). 1,25-(OH) 2 -Vitamin $\mathrm{D}_{3}$ inhibits the proliferation and activation of $\mathrm{T}$ cells and $\mathrm{T}$ and $\mathrm{B}$ lymphocytes (Martineau et al., 2017). Thus, vitamin $\mathrm{D}_{3}$ suppresses T-cell-mediated inflammation and promote the proliferation of Treg cells that results in an increase in the production of IL-10 that leads to suppression of inappropriate inflammation (Adorini and Penna, 2009; Chun et al., 2014). Vitamin $\mathrm{D}_{3}$ can also increase the expression of glutathione reductase and glutamate-cysteine ligase modifier subunit (Lei et al., 2017) that may lead to a decrease in oxidative stress. These results led to the proposal that (Biancatelli et al., 2019; Mousavi et al., 2019; Wimalawansa, 2020) vitamin $\mathrm{D}_{3}$ may be of benefit to combat SARS-CoV-2 infection (Grant et al., 2020a).

Vitamin D deficiency is common in patients with HIV (Herr et al., 2007). The antiviral action of vitamin $D_{3}$ can also be attributed to its ability to increase the production of cathelicidin and defensins (Herr et al., 2007; Hughes and Norton, 2009; Beard et al., 2011). Furthermore, 1,25-dihydroxy-cholecalciferol is known to regulate more than 200 genes including those responsible for cell proliferation, differentiation, and apoptosis (Umar and Sastry, 2018) including those involved in immune homeostasis (Van Herwegen et al., 2017). Recent meta-analysis of randomized controlled trials (RCTs) showed that vitamin D deficiency increases the overall mortality (Bjelakovic et al., 2014; Keum et al., 2019; Manson et al., 2019; Scragg, 2020). All above-mentioned effects of Vitamin $\mathrm{D}_{3}$ are presented in Table 1.

\section{RELEVANCE OF VITAMIN D REGARDING TO RESPIRATORY TRACT INFECTIONS AND INFLUENZA}

There is a provided evidence given by many reviewed studies to support the hypothesis that higher serum level of vitamin $\mathrm{D}_{3}$ is associated with a low risk of microbial infections and deaths from RTIs caused by pneumonia and influenza. In addition, SARSCoV-2 infection and decrease the severity and mortality may be avoided by a normal serum vitamin $\mathrm{D}_{3}$ levels (Wimalawansa, 2020). Unfortunately, there are no standard recommendations regarding the dose and the desired optimal concentration of vitamin $\mathrm{D}_{3}$ required to protect people from RTI during the winter season.

Epidemiological studies revealed that vitamin $\mathrm{D}_{3}$ plays a critical role in viral RTIs and associated acute lung injury (Hansdottir and Monick, 2011). In a recent meta-analysis, it has been shown that a daily or weekly vitamin $\mathrm{D}_{3}$ dose between 20 and $50 \mu \mathrm{g}$ resulted in a significant reduction of RTIs (Martineau et al., 2017). A high-dose, isolated, or added bolus of (2.5 mg once or monthly) did not reduce the risk. One study supplemented for one-year high risk individual for ARDS with a $100 \mu \mathrm{g} /$ daily (Bergman et al., 2012). The overall infection score was significantly reduced in the treated groups, and those with vitamin $\mathrm{D}_{3}$ deficiency showed the greatest benefit of the supplementation.

In addition, it is observed that the degree of protection generally increases when the concentration of vitamin $D_{3}$ reaches its optimal range of 40 to $60 \mathrm{ng} / \mathrm{ml}$. To reach this level, an individual must take between 2,000 and 5,000 IU/day of vitamin $\mathrm{D}_{3}$ (Heaney et al., 2003). Calcitriol protects against acute lung injury by modulating the expression of the renin-angiotensin system including angiotensin-converting enzyme 2 (ACE2) in lung tissue (Xu et al., 2017). There seems to be a direct relationship between plasma 25- $(\mathrm{OH})-\mathrm{Vitamin} \mathrm{D}_{3}$ concentrations and severity of COVID-19 (Huang et al., 2020; Wang et al., 2020; Zhou et al., 2020). It is noteworthy that the expression of the DPP-4/CD26 receptor is significantly reduced as a result of vitamin $\mathrm{D}_{3}$ deficiency (Komolmit et al., 2017). Furthermore, adequate provision of vitamin $D_{3}$ seems to attenuate immunological events that may lead to prolonged interferon-gamma response (Zdrenghea et al., 2017), and persistent interleukin six elevation that are negative prognostic value indicators in those with severe COVID-19 (Miroliaee et al., 2018).

VDRs are very widely distributed in respiratory epithelial cells and immune cells (B cells, T cells, macrophages and monocytes). VDRs are in the epithelium of the bronchi and immune cells (Pfeffer and Hawrylowicz, 2012). The enzyme, 1a-hydroxylase (CYP27B1), required for vitamin D activation, is induced by diverse stimuli, including cytokines and toll-like receptor ligands in the respiratory tract. Nevertheless, adequate serum levels of 25$(\mathrm{OH})$-vitamin $\mathrm{D}_{3}$ is required to increase levels of $1,25-(\mathrm{OH})_{2}$ vitamin $\mathrm{D}_{3}$ and to improve the immune response to respiratory virus infections (Greiller and Martineau, 2015). The development 
of ARDS shows typical changes in membrane permeability of the alveolar capillary, progressive edema, severe arterial hypoxemia and pulmonary hypertension (Matthay et al., 2012). In animal studies, vitamin $\mathrm{D}_{3}$ significantly attenuated lung damage caused by lipopolysaccharides (LPS) (Xu et al., 2017). This is noteworthy since LPS increase the pulmonary expression of renin and angiotensin 2 (Ang 2) that promotes inflammation. Vitamin $\mathrm{D}_{3}$ reduces the increased renin and Ang 2 expression and thus significantly lowers lung injury. It has been suggested that vitamin $\mathrm{D}_{3}$ promotes ACE2/Ang 1-7 activity. This is supported by the observation that calcitriol treatment significantly increased the expression of VDR mRNA and ACE2 mRNA that leads to a reduction in angiotensin II, ACE2 expression resulting in suppression of inflammation (Yang et al., 2016). VDRs are not only a negative regulator of renin, but also of $\mathrm{NF}-\mathrm{kB}$ ( $\mathrm{Li}$ et al., 2004), leading to an increase in Ang 2 formation, which promotes pro-inflammation (Jurewicz et al., 2007).

Down-regulation of ACE2 expression by SARS-CoV infection is associated with acute lung damage (edema, increased vascular permeability, reduced lung function) and associated RAS dysregulation leads to increased inflammation and vascular permeability as seen in COVID-19 (Imai et al., 2005). It was reported that COVID-19 is associated with release of pro-vitamin $\mathrm{D}_{3}$ enhances the cellular immunity and reduces the cytokine storm induced by the innate immune system. Vitamin $\mathrm{D}_{3}$ can reduce the production of pro-inflammatory cytokines such as TNF- $\alpha$ and IF- $\gamma$ (Tjabringa et al., 2005; Baeke et al., 2010; Laaki, 2012). Several studies showed that adequate intake and plasma levels of vitamin $\mathrm{D}_{3}$ reduces the risk of viral infections through their action on immunocytes (Carnell et al., 2006; Baeke et al., 2010; Schwalfenberg, 2011; Lang and Samaras, 2012). Hence, it is suggested that vitamin $\mathrm{D}_{3}$ may have a significant role in COVID19 due to its action on T cells (Zhang et al., 2015).

Type-II pneumocytes which are the primary target of coronaviruses, express high levels of ACE2 receptor (Bombardini and Picano, 2020). Metabolites of 25-(OH)vitamin $\mathrm{D}_{3}$ have been reported to stimulate surfactant synthesis in alveolar type-II cells (Rehan et al., 2002). Human fetal and adult alveolar type-II cells supplemented with 1,25dihydroxy-vitamin $D_{3}$ show increased levels of VDRs and expression of surfactant associated protein B, a lipid-associated protein of the pulmonary surfactant, indicating the potential of vitamin $\mathrm{D}_{3}$ to reduce surface tension in COVID-19 (Phokela et al., 2005).Comorbid conditions such as diabetes mellitus, hypertension and chronic obstructive pulmonary disease are commonly associated with low plasma vitamin $\mathrm{D}_{3}$ levels (Malinovschi et al., 2014; Kim et al., 2015; Grant et al., 2020a). Hence, it is reasonable to propose that COVID-19 may be associated with low plasma vitamin $\mathrm{D}_{3}$ levels. Hence, it is suggested that vitamin $\mathrm{D}_{3}$ supplementation may be of significant benefit in COVID-19. Grant, in the latest report, suggest that vitamin $\mathrm{D}$ level checking will be conducted only in as elected category of patients that involves pregnant mothers, obese and elderly people and others suffering from certain comorbid conditions (Grant et al., 2020b). Multiple factors such as an ability of the assimilation by the gastrointestinal tract, body weight, genetic factors and the baseline 25-(OH)- vitamin $\mathrm{D}_{3}$ concentration, control the increase in vitamin $\mathrm{D}$ concentrations with respect to oral vitamin $\mathrm{D}_{3}$ supplementation. Given the degree of vitamin $\mathrm{D}_{3}$ deficiency, taking $5,000 \mathrm{IU}$ of vitamin per day, it could be essential to elevate $25-(\mathrm{OH})$-vitamin $\mathrm{D}_{3}$ levels to $40 \mathrm{ng} / \mathrm{ml}$ by (Veugelers et al., 2015).

A recent article indicates that vitamin $D_{3}$ value $>20 \mathrm{ng} / \mathrm{ml}$ is required and this advice is adopted by several countries (Amrein et al., 2020). Another research suggests a higher dose for RTIs, indicating rates $>30 \mathrm{ng} / \mathrm{ml}$ of vitamin $\mathrm{D}_{3}$ as effective in decreasing cancer incidence, unfavorable pregnancy and birth outcomes and type 2 diabetes mellitus (Grant et al., 2020b). From another analysis it is suggested that optimal vitamin $\mathrm{D}_{3}$ standard should be $40-60 \mathrm{ng} / \mathrm{ml}$ for prevention of breast and colorectal cancer (Garland et al., 2009).

The U.S. Institute of Medicine noted that no research observed negative consequences of supplementation of vitamin $\mathrm{D}_{3}$ of less than $10,000 \mathrm{IU} /$ daily, but set the upper consumption limit at $4,000 \mathrm{IU} /$ daily, partially owing to retrospective tests that found U-shaped 25-(OH)-vitamin $\mathrm{D}_{3}$ concentration/health outcome relationships. However, further findings indicate that most observations of $\mathrm{J}$ - or U-shaps relationships came from observational studies that did not test serum 25-(OH)-vitamin $\mathrm{D}_{3}$ concentrations, and that the likely explanation for these relationships was the presence of some participants who started taking vitamin $\mathrm{D}_{3}$ complementation shortly before registration (Grant et al., 2016). Particularly in winter, supplementation with vitamin $\mathrm{D}_{3}$ is required for many individuals to reach concentrations of 25- $(\mathrm{OH})$-vitamin $\mathrm{D}_{3}$ above $30 \mathrm{ng} / \mathrm{ml}$ (Pludowski et al., 2018). However, vitamin $\mathrm{D}_{3}$ fortification of basic foods such as dairy and flour products may increase serum $25(\mathrm{OH}) \mathrm{D}$ concentrations by a few $\mathrm{ng} / \mathrm{ml}$ among those members of different populations with the lowest concentrations (Pilz et al., 2018; Grant and Boucher 2019). This will contribute to a decreased risk of ARTIs for persons with a severe vitamin $\mathrm{D}_{3}$ deficiency (Camargo et al., 2012; Martineau et al., 2017). However, regular or weekly treatment of vitamin $\mathrm{D}_{3}$ is advised for greater benefits (Martineau et al. $2017)$, as is the annual evaluation of serum 25-(OH)-vitamin $D_{3}$ levels for health risks individuals (Grant et al., 2020b).

Table 2 describes the findings from meta-analyses that vitamin $\mathrm{D}_{3}$ is protective against acute RTI, particularly in patients with vitamin $\mathrm{D}_{3}$ deficiency.

\section{HYPOTHESIS OF THE CORRELATION ON VITAMIN $D_{3}$ LEVELS AND CORONAVIRUS DISEASE-19 CASES/SEVERITY}

Still there is a lack of a cohort studies and clinical trials in determining the role of vitamin $\mathrm{D}_{3}$ in the prevention of COVID-19 infections and/or severity. Some retrospective studies have demonstrated the relationships between vitamin $\mathrm{D}_{3}$ levels and COVID-19 cases and severity (Table 3).

For example, a preliminary information study from Philippines on 212 reported COVID-19 patients, found that the severity of the infection is a highly correlated to the 
TABLE 2 | The finding on the efficacy of vitamin $\mathrm{D}$ in the respiratory tract infections.

\begin{tabular}{|c|c|c|c|}
\hline Participants & Study characteristics & Vitamin D effect & References \\
\hline $\begin{array}{l}5,660 \text { participants (age ranging from } \\
6 \text { months to } 75 \text { years) }\end{array}$ & $\begin{array}{l}\text { Eleven randomized placebo- } \\
\text { controlled trials }\end{array}$ & $\begin{array}{l}\text { Supplementation with vitamin D significantly decreased the risk of RTI (OR: } \\
0.64 ; 95 \% \mathrm{Cl}: 0.49,0.84 ; p=0.0014)\end{array}$ & $\begin{array}{l}\text { Bergman et al. } \\
\text { (2013) }\end{array}$ \\
\hline 1,868 participants (aged 1-83 years) & Five clinical trials & $\begin{array}{l}\text { The reduction of episodes of RTI was significantly lower in vitamin D } \\
\text { supplementation group compared to the control group (OR }=0.58 ; 95 \% \\
\mathrm{Cl}: 0.42,0.81 ; p=0.001)\end{array}$ & $\begin{array}{l}\text { Charan et al. } \\
\text { (2012) }\end{array}$ \\
\hline $\begin{array}{l}\text { 10,933 participants (aged 0-95 years) } \\
\text { from } 14 \text { different countries }\end{array}$ & $\begin{array}{l}\text { Twenty five randomized } \\
\text { controlled trials }\end{array}$ & $\begin{array}{l}\text { Overall results showed that vitamin D supplementation has protective } \\
\text { effective in decreasing the risk of suffering at least one acute RTI (OR 0.88; } \\
95 \% \mathrm{Cl}: 0.81,0.96 ; p=0.003)\end{array}$ & $\begin{array}{l}\text { Martineau et al. } \\
\text { (2017) }\end{array}$ \\
\hline
\end{tabular}

OR, Odds ratio; $R T I$, Respiratory tract infection; $\mathrm{Cl}$, Confidence interval.

vitamin $\mathrm{D}_{3}$ levels (Alipio, 2020). Authors have found that $85.5 \%$ of patients with an adequate status of vitamin $\mathrm{D}_{3}(>30 \mathrm{ng} / \mathrm{ml})$ showed a moderate disease, while a $72.8 \%$ of patients with vitamin $\mathrm{D}_{3}$ deficiency $(<20 \mathrm{ng} / \mathrm{ml})$ had the serious disease symptoms (Alipio, 2020). The correlation between vitamin $\mathrm{D}_{3}$ and COVID-19 have extensively investigated in a group of 178 Indonesians (Raharusun et al., 2020). According to this study, the patients with vitamin $\mathrm{D}_{3}$ levels in the categories, 20-30 and $<20 \mathrm{ng} / \mathrm{ml}$, were 12.55 times and 19.12 times more likely to die from COVID-19, respectively, as compared with COVID19 patients with sufficient levels of vitamin $\mathrm{D}_{3}$. The main conclusion is that, even after controlling for age, sex and comorbidities, deaths were 10.12 times more likely in patients with vitamin $\mathrm{D}_{3}$ deficiency than in patients with normal vitamin $\mathrm{D}_{3}$ levels (Raharusun et al., 2020). A limited cohort observational study with 43 cases in Singapore have found that a treatment of COVID-19 patients with an oral doses of vitamin $\mathrm{D}_{3}$ (1.000 IU), $\mathrm{Mg}(150 \mathrm{mg})$, and vitamin $\mathrm{B}_{12}(500 \mu \mathrm{g})$ significantly reduced the application of the subsequent oxygen therapy compared to controls (3/17 vs. 16/26, $p=0.006$ ) (Tan et al., 2020). Furthermore, such drugs combination have protected against the clinical deterioration $(\mathrm{p}=0.041)$ even after adjustment of confounders (age, sex and comorbidity) (Tan et al., 2020). Severe COVID-19 patients and patients with pre-existing medical conditions were reported to have low levels of vitamin $D_{3}$ (Glicio et al., 2020; Lau et al., 2020). A retrospective observational study with 186 positive cases and 2717 negative controls in Belgium have demonstrated a low median for vitamin $\mathrm{D}_{3}$ in the COVID-19 patients compared to the control subjects ( $p=0.0016$ ) (De Smet et al., 2020). A retrospective cohort study with 780 cases in Indonesia showed that below-normal vitamin $\mathrm{D}_{3}$ levels and the pre-existing medical conditions in the older and male cases have higher odds of death. Moreover, the vitamin $\mathrm{D}_{3}$ status has a strong relationship with COVID-19 mortality if it adjusted for age, sex and comorbidities (Raharusun et al., 2020). The similar retrospective study in the USA with many cases have showed that the reduced risks for both COVID-19 cases and the mortality are possibly associated with the sunlight and vitamin $\mathrm{D}_{3}$, as well with the latitude as an indicator (Li et al., 2020).

In a new systematic review and meta-analysis with an ecological approach, they found a high percentage of COVID19 patients who suffer from vitamin $\mathrm{D}_{3}$ deficiency or insufficiency. Much more important its ecological investigation resulted in the substantial direct and reverse correlations between the recovery and mortality rates in COVID-19 patients with vitamin $\mathrm{D}_{3}$ deficiency at the different countries. A small reverse correlation between vitamin $\mathrm{D}_{3}$ status and the mortality rate have found globally. The populations with a lower levels of vitamin $\mathrm{D}_{3}$ might be more susceptible to the novel coronavirus infection (Ghasemian et al., 2020). Recently, a cohort study of 489 patients who had a vitamin $\mathrm{D}_{3}$ levels detected in the year before COVID19 testing was 1.77 times greater for patients with vitamin $\mathrm{D}_{3}$ deficiency compared to the patients with a normal vitamin $\mathrm{D}_{3}$ status. These findings appear to support a role of vitamin $\mathrm{D}_{3}$ status for the COVID-19 risk (Meltzer et al., 2020).

The hypothesis that supplementation with vitamin $\mathrm{D}_{3}$ may reduce the risk of influenza and COVID-19 disease, as well the death should be examined in the trials to evaluate the correct doses, the serum 25-(OH)-vitamin $\mathrm{D}_{3}$ concentrations and the existence of any health concerns. There are a good model from Atlanta and Georgia in which have done the RCT on vitamin $\mathrm{D}_{3}$ supplementation for the ventilated ICU patients (Han et al., 2016).

There is a recommendation to take a vitamin $\mathrm{D}_{3}$ at $10,000 \mathrm{IU} /$ day as an acceptable dose to raise circulatory concentration of vitamin $\mathrm{D}_{3}$ to the optimum range of $40-60 \mathrm{ng} / \mathrm{ml}$; after $1 \mathrm{month}$ this dose should be lowered to 5,000 IU/day to the sustain serum rate (Ekwaru et al., 2014; Shirvani et al., 2019). A recent study have suggested a loading doses of 200,000-300,000 IU of vitamin $\mathrm{D}_{3}$ to reach the optimum serum range, thereby the reducing of the risk/severity for COVID-19 (Wimalawansa, 2020).

The observation that normal vitamin $\mathrm{D}_{3}$ status is important for the immune system as well as for the regulation of SAR should lead to a correction of vitamin $\mathrm{D}_{3}$ status if a deficiency has been detected. There is no experience with the use of vitamin $\mathrm{D}_{3}$ in COVID-19. In addition, it should be noted that a very high doses of the upper limit of $4,000 \mathrm{IU}(100 \mu \mathrm{g})$ per day of vitamin $\mathrm{D}_{3}$ still have the risks and may be dangerous. Since such doses might result in to the improvements in the VDR competency and could have an inhibitory impact on the immune function (Mangin et al., 2014).

\section{CONCLUSION}

It is evident from the preceding discussion that vitamin $\mathrm{D}_{3}$ may be of benefit in COVID-19. Since the higher plasma concentrations of vitamin $\mathrm{D}_{3}$ is better for the protection from 
TABLE 3 | The outcomes in recent studies about the correlation of vitamin $D_{3}$ concentrations with COVID-19 infections.

\begin{tabular}{|c|c|c|c|c|c|c|}
\hline Country & Population type & $\mathbf{n}$ & Study design & $\begin{array}{l}\text { Vitamin } \mathrm{D}_{3} \\
\text { doses }\end{array}$ & Outcomes & Reference \\
\hline $\begin{array}{l}\text { Singapore (a tertiary } \\
\text { academic hospital) }\end{array}$ & $\begin{array}{l}\text { Adults, age } \\
\geq 50 \text { years }\end{array}$ & 43 & Cohort observational & $\begin{array}{l}\text { Vitamin } D_{3} 1,000 \mathrm{lU}, \\
\text { Mg } 150 \mathrm{mg}, \text { and } \\
\text { vitamin } \mathrm{B}_{12} 500 \mu \mathrm{g} \\
\text { (oral) }\end{array}$ & $\begin{array}{l}\text { i) A fewer patients who received } \\
\text { vitamin } D_{3}, M g \text { and vitamin } B_{12} \\
\text { required the subsequent oxygen } \\
\text { therapy compared to controls ( } 3 \text { / } \\
17 \text { vs. } 16 / 26, p=0.006 \text { ) } \\
\text { ii) in multivariate analysis, the } \\
\text { patients treatment with vitamin } D_{3} \text {, } \\
\text { Mg and vitamin } B_{12} \text { have showed a } \\
\text { significant protective effects } \\
\text { against clinical deterioration ( } p= \\
\text { 0.041) after adjusting for age, } \\
\text { gender and comorbidities }\end{array}$ & Tan et al., 2020 \\
\hline 20 European countries & Adults & $\begin{array}{l}\text { Cases and } \\
\text { death/1 M } \\
\text { population }\end{array}$ & Retrospective & NA & $\begin{array}{l}\text { A significant negative correlation } \\
\text { was observed for the serum 25- } \\
(\mathrm{OH}) \text {-vitamin } D_{3} \text { levels with COVID- } \\
19 \text { cases }(p=0.033) \text { but not with a } \\
\text { death }(p=0.123) \text { per million of } \\
\text { population }\end{array}$ & Present study \\
\hline 20 European countries & Adults & $\begin{array}{l}\text { Cases and } \\
\text { death/1 M } \\
\text { population }\end{array}$ & $\begin{array}{l}\text { Retrospective (as of } 8 \\
\text { April 2020) }\end{array}$ & NA & $\begin{array}{l}\text { A negative correlation was } \\
\text { observed between the serum 25- } \\
(O H) \text {-vitamin } D_{3} \text { levels and COVID- } \\
19 \text { cases }(p=0.050 \text { ) and a death ( } p \\
=0.053 \text { ) per million of population }\end{array}$ & Ilie et al. (2020) \\
\hline Southern Asian countries & NA & 222 & $\begin{array}{l}\text { Retrospective } \\
\text { multicentral study }\end{array}$ & NA & $\begin{array}{l}\text { i) The differences in the levels of } \\
\text { vitamin } D_{3} \text { mean were significant } \\
\text { within the mild, ordinary, severe } \\
\text { and critical cases of COVID-19 }(p< \\
0.001) \\
\text { ii) Vitamin } D_{3} \text { status showed a } \\
\text { significant association with clinical } \\
\text { outcomes ( } p<0.001)\end{array}$ & Alipio (2020) \\
\hline $\begin{array}{l}\text { USA (a single tertiary } \\
\text { academic medical center) }\end{array}$ & $\begin{array}{l}\text { Adults, mean age } \\
65.2 \text { years }\end{array}$ & 20 & $\begin{array}{l}\text { Retrospective } \\
\text { observational study }\end{array}$ & NA & $\begin{array}{l}\text { A high vitamin } D_{3} \text { insufficiency was } \\
\text { observed in ICU patients ( } 84.6 \%) \\
\text { than in the floor patients }(57.1 \%)(p \\
=0.29 \text { ) }\end{array}$ & Lau et al. (2020) \\
\hline $\begin{array}{l}\text { South Asia (two tertiary } \\
\text { medical centers) }\end{array}$ & $\begin{array}{l}\text { Adults, age } \\
\geq 60 \text { years }\end{array}$ & 176 & Retrospective & NA & $\begin{array}{l}\text { i) Severe patients had a low level of } \\
\text { vitamin } D \text { than mild patients } \\
\text { ii) Subjects with the pre-existing } \\
\text { medical conditions had a low level } \\
\text { of vitamin } D_{3}\end{array}$ & $\begin{array}{l}\text { Glicio et al. } \\
(2020)\end{array}$ \\
\hline $\begin{array}{l}\text { UK (UK Biobank data } \\
\text { 2006-2010 for vitamin } D_{3} \text { and } \\
\text { ethnicity) }\end{array}$ & $\begin{array}{l}\text { Adults, age } \\
37-73 \text { years }\end{array}$ & 449 & $\begin{array}{l}\text { Cross-sectional (16 } \\
\text { March-14 April 2020) }\end{array}$ & NA & $\begin{array}{l}\text { i) Vitamin } D_{3} \text { levels showed a } \\
\text { significant association with COVID- } \\
19 \text { infection in an univariate } \\
\text { analysis ( } p=0.013 \text { ) but not after an } \\
\text { adjustment for confounders ( } p= \\
0.208 \text { ) } \\
\text { ii) Ethnicity showed a significant } \\
\text { association with COVID-19 } \\
\text { infection univariably }\end{array}$ & $\begin{array}{l}\text { Hastie et al. } \\
(2020)\end{array}$ \\
\hline
\end{tabular}

(Continued on following page) 
TABLE 3 | (Continued) The outcomes in recent studies about the correlation of vitamin $\mathrm{D}_{3}$ concentrations with COVID-19 infections.

\begin{tabular}{|c|c|c|c|c|c|c|}
\hline Country & Population type & $\mathbf{n}$ & Study design & $\begin{array}{l}\text { Vitamin } \mathrm{D}_{3} \\
\text { doses }\end{array}$ & Outcomes & Reference \\
\hline $\begin{array}{l}\text { United Kingdom (UK Biobank } \\
\text { data } 20062010 \text { for BMI, } \\
\text { vitamin } D_{3} \text { and ethnicity) }\end{array}$ & $\begin{array}{l}\text { Adults, mean age } \\
57.7 \text { years }\end{array}$ & $\begin{array}{l}580 \text { cases and } \\
723 \text { control }\end{array}$ & Retrospective & NA & $\begin{array}{l}\text { i) No significant difference was } \\
\text { observed for vitamin } D_{3} \text { levels } \\
\text { between COVID-19 cases and the } \\
\text { control group } \\
\text { ii) Vitamin } D_{3} \text { status was } \\
\text { significantly lower in those of Asian, } \\
\text { Black and mixed ethnicity ( } p< \\
\text { 0.0010) compared with those of } \\
\text { White ethnicity } \\
\text { iii) Vitamin } D_{3} \text { levels were } \\
\text { significantly lower in those with } \\
\text { obesity ( } p \text { <.001). Overweight or } \\
\text { obese person; living in London; } \\
\text { being male and being of Asian, } \\
\text { Black or mixed ethnicity was } \\
\text { associated with a higher odd of } \\
\text { positive cases } \\
\text { iv) In the regression model, the } \\
\text { interaction between BMl and } \\
\text { vitamin } D_{3} \text { status did not predict } \\
\text { the test result in the available data } \\
\text { set }\end{array}$ & $\begin{array}{l}\text { Darling et al. } \\
(2020)\end{array}$ \\
\hline $\begin{array}{l}\text { Mainland of United States (48 } \\
\text { states and Columbia district) }\end{array}$ & $\begin{array}{l}1.609 .488 \text { cases and } \\
91.094 \text { deaths }\end{array}$ & - & $\begin{array}{l}\text { Retrospective (22 } \\
\text { Jan-23 May 2020) }\end{array}$ & NA & $\begin{array}{l}\text { i) Latitudes were marginally } \\
\text { associated with the cases ( } p= \\
0.0792) \text { and the deaths ( } p= \\
0.0599) \\
\text { ii) Sunlight and vitamin } \mathrm{D}_{3} \text {, with } \\
\text { latitude as an indicator, possibly } \\
\text { associated with reduced risks for } \\
\text { both COVID-19 cases and } \\
\text { mortality }\end{array}$ & Li et al. (2020) \\
\hline $\begin{array}{l}\text { Belgium (central network } \\
\text { hospital) }\end{array}$ & $\begin{array}{l}\text { Adults, median age } \\
71 \text { years (cases), } \\
68 \text { years (control) }\end{array}$ & $\begin{array}{l}186 \text { cases, } \\
2,717 \text { controls }\end{array}$ & $\begin{array}{l}\text { Retrospective } \\
\text { observational (1 } \\
\text { March-7 April 2020) }\end{array}$ & NA & $\begin{array}{l}\text { i) Patients with COVID- } 19 \text { had } \\
\text { significantly a low median value of } \\
\text { vitamin } D_{3} \text { and higher vitamin } D_{3} \\
\text { deficiency compared to control } \\
\text { subjects ( } p=0.0016, p=0.0005 \text {, } \\
\text { respectively) } \\
\text { ii) This difference were more } \\
\text { pronounced in male COVID-19 } \\
\text { subjects than male control } \\
\text { subjects that increased with } \\
\text { advancing radiological stage and } \\
\text { were not confounded vitamin } D_{3}- \\
\text { impacted comorbidities }\end{array}$ & $\begin{array}{l}\text { De Smet et al. } \\
(2020)\end{array}$ \\
\hline $\begin{array}{l}\text { Hospitals and clinics from } \\
\text { different parts of the world }\end{array}$ & Age up to 80 years & 5,000 cases & As on March 21, 2020 & NA & $\begin{array}{l}\text { About } 15 \% \text { reduction in the } \\
\text { number of severe COVID-19 cases } \\
\text { given a normal vitamin } D_{3} \text { status } \\
\text { within a population }\end{array}$ & $\begin{array}{l}\text { Daneshkhah } \\
\text { et al. (2020) }\end{array}$ \\
\hline $\begin{array}{l}\text { Indonesia (Government } \\
\text { hospital) }\end{array}$ & $\begin{array}{l}\text { Adults, mean age } \\
54.5 \text { years }\end{array}$ & 780 cases & $\begin{array}{l}\text { Retrospective cohort } \\
\text { study (2 March 2-24 } \\
\text { April 2020) }\end{array}$ & NA & $\begin{array}{l}\text { i) In univariate analysis, older and } \\
\text { male cases with the pre-existing } \\
\text { medical condition and below } \\
\text { normal vitamin } \mathrm{D}_{3} \text { levels were } \\
\text { associated with the higher odds of } \\
\text { death } \\
\text { ii) After adjustment of confounders } \\
\text { (age, sex and comorbidity), vitamin } \\
D_{3} \text { levels showed a strong } \\
\text { relationship with the COVID-19 } \\
\text { mortality }\end{array}$ & $\begin{array}{l}\text { Raharusun } \\
\text { et al. (2020) }\end{array}$ \\
\hline
\end{tabular}


various viral and respiratory infections, it is reasonable to suggest that regular supplementation of vitamin $\mathrm{D}_{3}$ to those who are at high risk of developing various viral respiratory infections including COVID-19 need to considered seriously. To verify this proposal, double-blind placebo-controlled trials and largescale intervention and prevention studies using vitamin $\mathrm{D}_{3}$ are needed. If this proposal is true it leads to the development of a simple, easily implementable method of preventing the incidence of COVID-19 and reducing its serious complications by simple oral supplementation of vitamin $\mathrm{D}_{3}$. Furthermore, vitamin $\mathrm{D}_{3}$ has several other benefits in the form of preventing rickets, improving

\section{REFERENCES}

Adams, J. S., Ren, S., Liu, P. T., Chin, R. F., Lagi Shetty, V., Gombart, A. F., et al. (2009). Vitamin d-directed rheostatic regulation of monocyte antibacterial responses. J. Immunol. 182, 4289-4295. doi:10.4049/ jimmunol.0803736

Adorini, L., and Penna, G. (2009). Dendritic cell tolerogenicity: a key mechanism in immunomodulation by vitamin D receptor agonists, Hum. Immunol. 70 (5), 345-352. doi:10.1016/j.humimm.2009.01.016

Agier, J., Efenberger, M., and Brzezińska-Błaszczyk, E. (2015). Cathelicidin impact on inflammatory cells. Cent. Eur. J. Immunol. 40, 225-235. doi:10.5114/ceji. 2015.51359

Alipio, M. M. (2020). Letter-preprint vitamin D supplementation could possibly improve clinical outcomes of patients infected with coronavirus-2019 (Covid2019). Available at: https://www.ssrn.com/abstract=3571484 (Accessed 09 May, 2020).

Amrein, K., Scherkl, M., Hoffmann, M., Neuwersch-Sommeregger, S., Köstenberger, M., Berisha, A. T., et al. (2020). Vitamin D deficiency 2.0: an update on the current status worldwide. Eur. J. Clin. Nutr. 20, 1-16. doi:10. 1038/s41430-020-0558-y

Aranow, C. (2011). Vitamin D and the immune system. J. Invest. Med. 59, 881-886. doi:10.2310/JIM.0b013e31821b8755

Baeke, F., Takiishi, T., Korf, H., Gysemans, C., and Mathieu, C. (2010). Vitamin D: modulator of the immune system. Curr. Opin. Pharmacol. 10, 482-496. doi:10. 1016/j.coph.2010.04.001

Bals, R., and Wilson, J. (2003). Cathelicidins-a family of multifunctional antimicrobial peptides. Cell. Mol. Life Sci. 60, 711-720. doi:10.1007/s00018003-2186-9

Barlow, P., Svoboda, P., Mackellar, A., Nash, A., York, I., Pohl, J., et al. (2011). Antiviral activity and increased host defense against influenza infection elicited by the human cathelicidin LL-37. PLoS One. 6, e25333. doi:10.1371/journal. pone. 0025333

Berardi, R., and Newton, G. (2009). Handbook of nonprescription drugs. 16th Edition. Washington DC: American Pharmacists Association, 1050

Bergman, P., Walter-Jallow, L., Broliden, K., Agerberth, B., and Soderlund, J. (2007). The antimicrobial peptide LL-37 inhibits HIV-1 replication. Curr. HIV Res. 5:410-415. doi:10.2174/157016207781023947

Bergman, P., Lindh, Å., Björkhem-Bergman, L., and Lindh, J. (2013). Vitamin D and respiratory tract infections: a systematic review and meta-analysis of randomized controlled trials. PloS One 8, e65835. doi:10.1371/journal.pone. 0065835

Bergman, P., Norlin, A. C., Hansen, S., Rekha, R. S., Agerberth, B., BjorkhemBergman, L., et al. (2012). Vitamin $\mathrm{D}_{3}$ supplementation in patients with frequent respiratory tract infections: a randomized and double-blind intervention study. BMJ Open 2, e001663. doi:10.1136/bmjopen-2012-001663

Biancatelli, R. C., Berrill, M., and Marik, P. (2019). The antiviral properties of vitamin C. Expert. Rev. Anti Infect. Ther. 18, 99-101. doi:10.1080/14787210. 2020.1706483

Biesalski, H. K. (2020). Vitamin D deficiency and co-morbidities in COVID-19 patients - a fatal relationship? NFS J. 20, 10-21. doi:10.1016/j.nfs.2020.06.001

Bjelakovic, G., Gluud, L. L., Nikolova, D., Whitfield, K., Wetterslev, J., Simonetti, R. G., et al. (2014). Vitamin D supplementation for prevention of mortality in general health, and reducing mortality due to its deficiency (though the exact cause for this association is not clear) add strength to the concept that its supplementation is warranted.

\section{AUTHOR CONTRIBUTIONS}

$\mathrm{MB}, \mathrm{VI}, \mathrm{RM}, \mathrm{DB}$ interpreted the data from the literature. MB, VI, RM, JF, DB wrote the original draft. MB, VI, RM, JF, FD, LG, UD, AE-A reviewed, edited and drafted the manuscript, and approved the final version.

adults. Cochrane Database Syst. Rev. 1:CD007470. doi:10.1002/14651858. CD007470.pub3

Bombardini, T., and Picano, E. (2020). Angiotensin converting enzyme 2 as the molecular bridge between epidemiologic and clinical features of COVID-19. Can. J. Cardiol. 36 (5), 784.e1-784.e2. doi:10.1016/j.cjca.2020.03.026

Bowie, A., and Unterholzner, L. (2008). Viral evasion and subversion of patternrecognition receptor signalling. Nat. Rev. Immunol. 8, 911-922. doi:10.1038/ nri2436

Brockman-Schneider, R. A., Pickles, R. J., and Gern, J. E. (2014). Effects of vitamin $\mathrm{D}$ on airway epithelial cell morphology and rhinovirus replication. PLoS One 9 (1), e86755. doi:10.1371/journal.pone.0086755

Camargo, C. A., Jr., Ganmaa, D., Frazier, A. L., Kirchberg, F. F., Stuart, J. J., Kleinman, K., et al. (2012). Randomized trial of vitamin D supplementation and risk of acute respiratory infection in Mongolia. Pediatrics. 130, e561-e567. doi:10.1542/peds.2011-3029

Cao, D., and Norton, R. (2009). Vitamin D and respiratory health. Clin. Exp. Immunol. 158, 20-25. doi:10.1111/j.1365-2249.2009.04001.x

Cannell, J. J., Vieth, R., Umtau, J. C., Hollick, M. F., Grant, W. B., Madronich, S., et al. (2006). Epidemic influenza and vitamin D. Epid. Infect. 134, 1129-1140. doi:10.1017/S0950268806007175

Charan, J., Goyal, J., Saxena, D., and Yadav, P. (2012). Vitamin D for prevention of respiratory tract infections: a systematic review and meta-analysis. J. Pharmacol. Pharmacother. 3, 300-303. doi:10.4103/0976-500X.103685

Chen, S., Sims, G. P., Chen, X. X., Gu, Y. Y., Chen, S., and Lipsky, P. E. (2007). Modulatory effects of 1,25-dihydroxyvitamin D3 on human B cell differentiation. J. Immunol. 179, 1634-1647. doi:10.4049/jimmunol.179.3.1634

Chun, R. F., Liu, P. T., Modlin, R. L., Adams, J. S., and Hewison, M. (2014). Impact of vitamin D on immune function: lessons learned from genome-wide analysis. Front. Physiol. 5, 151. doi:10.3389/fphys.2014.00151

Daneshkhah, A., Agrawal, V., Eshein, A., Subramanian, H., Roy, H. K., and Backman, V. (2020). The possible role of vitamin D in suppressing cytokine storm and associated mortality in COVID-19 patients. Med Rxiv Preprint. doi:10.1101/2020.04.08.20058578

Daniel, C., Sartory, N. A., Zahn, N., Radeke, H. H., and Stein, J. M. (2008). Immune modulatory treatment of trinitrobenzene sulfonic acid colitis with calcitriol is associated with a change of a T helper (Th) $1 / \mathrm{Th} 17$ to a Th2 and regulatory T cell profile. J. Pharmacol. Exp. Therapeut. 324, 23-33. doi:10.1124/jpet.107. 127209

Darling, A. L., Ahmadi, K. R., Ward, K. A., Harvey, N. C., Alves, A. C., DunnWaters, D. K., et al. (2020). Vitamin D status, body mass index, ethnicity and COVID-19: Initial analysis of the first-reported UK Biobank COVID-19 positive cases (n 580) compared with negative controls (n 723). MedRxiv. doi:10.1101/2020.04.29.20084277

De Smet, D., De Smet, K., Herroelen, P., Gryspeerdt, S., and Martens, G. A. (2020) Vitamin D deficiency as risk factor for severe COVID-19: a convergence of two pandemics. Med Rxiv Preprint.doi:10.1101/2020.05.01.20079376

Di Rosa, M., Malaguarnera, M., Nicoletti, F., and Malaguarnera, L. (2011). Vitamin D3: a helpful immuno-modulator. Immunology 134, 123-139. doi:10.1111/j. 1365-2567.2011.03482.x

Donis, J., Bearden, A., and Striker, R. (2011). Vitamin D and the anti-viral state. J. Clin. Virol. 50, 194-200. doi:10.1016/j.jcv.2010.12.006

D’Ambrosio, D., Cippitelli, M., Cocciolo, M., Mazzeo, D., Di Lucia, P., Lang, R., et al. (1998). Inhibition of IL-12 production by 1,25-dihydroxyvitamin D3. 
Involvement of NF-kappaB downregulation in transcriptional repression of the p40 gene. J. Clin. Invest. 101, 252-262. doi:10.1172/JCI1050

Ekwaru, J., Zwicker, J., Holick, M., Giovannucci, E., and Veugelers, P. (2014). The importance of body weight for the dose response relationship of oral Vitamin D supplementation and serum 25 -hydroxyvitamin D in healthy volunteers. PLoS One 9, e111265. doi:10.1371/journal.pone.0111265

Fritsche, J., Mondal, K., Ehrnsperger, A., Andreesen, R., and Kreutz, M. (2003). Regulation of 25-hydroxyvitamin D3-1 alpha-hydroxylase and production of 1 alpha,25-dihydroxyvitamin D3 by human dendritic cells. Blood 102, 3314-3316. doi:10.1182/blood-2002-11-3521

Garland, C., Gorham, E., Mohr, S., and Garland, F. (2009). Vitamin D for cancer prevention: global perspective. Ann. Epidemiol. 19, 468-483. doi:10.1016/j. annepidem.2009.03.021

Ghasemian, R., Shamshirian, A., Heydari, K., Malekan, M., Alizadeh-Navaei, R., Ebrahimzadeh, M. A., et al. (2020). The role of vitamin D in the age of COVID19: a systematic review and meta-analysis along with an ecological approach. Med Rxiv Preprint. doi:10.1101/2020.06.05.20123554

Glicio, E. J., Neelam, S., Rashi, R., and Ramya, D. (2020). Vitamin D level of mild and severe elderly cases of COVID-19: a preliminary report. Available at: http:// vitaminad.nositio.eu/SSRN-id3593258.pdf

Godbole, H., Jang, J., Hong, K., Park, J., and Choi, E. (2015). Relationship between serum Vitamin D concentrations and clinical outcome of community-acquired pneumonia. Int. J. Tubercul. Lung Dis. 19, 729-734. doi:10.5588/ijtld.14.0696

Gombart, A. F., Pierre, A., and Maggni, S. (2020). A Review of micronutrients and immune-system working in Harmony to reduce the risk of Infection. Nutrition 12, 236. doi:10.3390/nu12010236

Gotlieb, N., Tachlytski, I., Lapidot, Y., Sultan, M., Safran, M., and BenAri, Z. (2018). Hepatitis B virus downregulates vitamin D receptor levels in hepatoma cell lines, thereby preventing vitamin Ddependent inhibition of viral transcription and production. Mol. Med. 24, 53. doi:10.1186/s10020-018-0055-0

Grant, W. B., and Boucher, B. J. (2019). A review of the potential benefits of increasing vitamin D status in Mongolian adults through food fortification and vitamin D supplementation. Nutrients 11, E2452. doi:10.3390/nu11102452

Grant, W. B., Karras, S. N., Bischoff-Ferrari, H. A., Annweiler, C., Boucher, B. J., et al. (2016). Do studies reporting 'U'-shaped serum 25-hydroxyvitamin D-health outcome relationships reflect adverse effects? Dermatoendocrinol 8, e1187349. doi:10.1080/19381980.2016.1187349

Grant, W. B., Anouti, F., and Moukayed, M. (2020b). Targeted 25 hydroxyvitamin D concentration measurement and vitamin D3 supplementation can have important patient and public health benefits. Eur. J. Clin. Nutr. 74, 366-376. doi:10.1038/s41430-020-0564-0

Grant, W., Lahore, H., McDonnell, S., Baggerly, C., French, C., Aliano, J., et al. (2020a). Evidence that Vitamin D supplementation could reduce risk of influenza and COVID-19 infections and deaths. Nutrients 12, 988. doi:10. 3390/nu12040988

Han, J. E., Jones, J. L., Tangpricha, V., Brown, M. A., Brown, L. A. S., Hao, L., et al. (2016). High dose vitamin D administration in ventilated intensive care unit patients: a pilot double blind randomized controlled trial. J. Clin. Transl. Endocrinol. 4, 59-65. doi:10.1016/j.jcte.2016.04.004

Hansdottir, S., Monick, M. M., Lovan, N., Powers, L., Gerke, A., and Hunninghake, G. W. (2010). Vitamin D decreases respiratory syncytial virus induction of NFkappaB-linked chemokines and cytokines in airway epithelium while maintaining the antiviral state. J. Immunol. 184, 965. doi:10.4049/jimmunol.0902840

Hansdottir, S., and Monick, M. M. (2011). Vitamin D effects on lung immunity and respiratory diseases. Vitam. Horm. 86, 217-237. doi:10.1016/B978-0-12386960-9.00009-5

Hastie, C. E., Mackay, D. F., Ho, F., Celis-Morales, C. A., Katikireddi, S. V., Niedzwiedz, C. L., et al. (2020). Vitamin D concentrations and COVID-19 infection in UK Biobank. Diabetes Metabol. Syndr. 14 (4), 561-565. doi:10. 1016/j.dsx.2020.04.050

Heaney, R., Davies, K., Chen, T., Holick, M., and Barger-Lux, M. (2003). Human serum 25-hydroxycholecalciferol response to extended oral dosing with cholecalciferol. Am. J. Clin. Nutr. 77, 204-210. doi:10.1093/ajcn/77.1.204

Herr, C., Shaykhiev, R., and Bals, R. (2007). The role of cathelicidin and defensins in pulmonary inflammatory diseases. Expet Opin. Biol. Ther. 7, 1449-1461. doi:10.1517/14712598.7.9.1449
Holick, C. L, and Martineau, A. R. (2015). Modulation of the immune response to respiratory viruses by vitamin D. Nutrients 7, 4240-4270. doi:10.3390/ nu7064240

Hollick, M. F. (2017). The vitamin D deficiency pandemic: approaches for diagnosis, treatment and prevention. Rev. Endocr. Metab. Disord. 18, 153-165. doi:10.1007/s11154-017-9424-1

Hollick, M. F. (2007). Vitamin D deficiency. N. Engl. J. Med. 357, 266-281. doi:10. 1056/NEJMra070553

Hope-Simpson, R. E. (1981). The role of season in the epidemiology of influenza. J. Hyg. 86, 35-47. doi:10.1017/S0022172400068728

Howell, M., Jones, J., Kisich, K., Streib, J., Gallo, R., and Leung, D. (2004). Selective killing of Vaccinia virus by LL-37: implications for eczema vaccinatum. J. Immunol. 172, 1763-1767. doi:10.4049/jimmunol.172.3.1763

Huang, C., Wang, Y., Li, X., Ren, L., Zhao, J., Hu, Y., et al. (2020). Clinical features of patients infected with 2019 novel coronavirus in Wuhan, China. Lancet 395, 497-506. doi:10.1016/S0140-6736(20)30183-5

Ilie, P. C., Stefanescu, S., and Smith, L. (2020). The role of vitamin D in the prevention of coronavirus disease 2019 infection and mortality. Aging Clin. Exp. Res. 32 (7), 1195-1198. doi:10.1007/s40520-020-01570-8

Imai, Y., Kuba, K., Rao, S., Huan, Y., Guo, F., Guan, B., et al. (2005). Angiotensinconverting enzyme 2 protects from severe acute lung failure. Nature 436, 112-116. doi:10.1038/nature 03712

Jurewicz, M., McDermott, D. H., Sechler, J. M., Tinckam, K., Takakura, A., Carpenter, C. B., et al. (2007). Human T and natural killer cells possess a functional renin-angiotensin system: further mechanisms of angiotensin IIinduced inflammation, J. Am. Soc. Nephrol. 18, 1093-1102. doi:10.1681/ASN. 2006070707

Kamen, D., and Tangpricha, V. (2010). Vitamin D and molecular actions on the immune system: modulation of innate and autoimmunity. J. Mol Med. 88, 441-450. doi:10.1007/s00109-010-0590-9

Keum, N., Lee, D. H., Greenwood, D. C., Manson, J. E., and Giovannucci, E. (2019). Vitamin D supplementation and total cancer incidence and mortality: a metaanalysis of randomized controlled trials. Ann. Oncol. 30, 733-743. doi:10.1093/ annonc/mdz059

Khare, D., Godbole, N. M., Pawar, S. D., Mohan, V., Pandey, G., Gupta, S., et al. (2013). Calcitriol $[1,25[\mathrm{OH}] 2$ D3] pre- and post-treatment suppresses inflammatory response to influenza A (H1N1) infection in human lung A549 epithelial cells. Eur. J. Nutr. 52, 1405-1415. doi:10.1007/s00394-0120449-7

Kmiec, P., Zmijewski, M., Waszak, P., Sworczak, K., and Lizakowska-Kmieć, M. (2014). Vitamin D deficiency during winter months among an adult, predominantly urban, population in Northern Poland. Endokrynol. Pol. 65, 105-113. doi:10.5603/EP.2014.0015

Komolmit, P., Charoensuk, K., Thanapirom, K., Suksawatamnuay, S., Thaimai, P., Chirathaworn, C., et al. (2017). Correction of vitamin D deficiency facilitated suppression of IP-10 and DPP IV levels in patients with chronic hepatitis C: a randomised double-blinded, placebo-control trial. PLoS One 12, e0174608. doi:10.1371/journal.pone. 0174608

Laaki, T. (2012). Vitamin D and respiratory infection in adults. Proc. Nutr. Soc. 71, 90-97. doi:10.1017/S0029665111003351

Lang, P. O., and Samaras, D. (2012). Aging adults and seasonal influenza: does the vitamin d status (h)arm the body? J. Aging Res. 2012, 806198. doi:10.1155/2012/ 806198

Lau, F. H., Majumder, R., Torabi, R., Saeg, F., Hoffman, R., Cirillo, J. D., et al. (2020). Vitamin D insufficiency is prevalent in severe COVID-19. Med Rxiv. doi:10.1101/2020.04.24.20075838

Lei, G., Zhang, C., Cheng, B., and Lee, C. (2017). Mechanisms of action of Vitamin $\mathrm{D}$ as supplemental therapy for pneumocystis pneumonia. Antimicrob. Agents Chemother. 61, e01226. doi:10.1128/AAC.01226-17

Leikina, E., Delanoe-Ayari, H., Melikov, K., Cho, M. S., Chen, A., Waring, A. J., et al. (2005). Carbohydrate-binding molecules inhibit viral fusion and entry by crosslinking membrane glycoproteins. Nat. Immunol. 6, 995-1001. doi:10. 1038/ni1248

Lemire, J. M., Archer, D. C., Beck, L., and Spiegelberg, H. L. (1995). Immunosuppressive actions of 1,25-dihydroxyvitamin D3: preferential inhibition of Th1 functions. J. Nutr. 125 (6 Suppl. 1), 1704S-1708S. doi:10. 1093/jn/125.suppl_6.1704S 
Li, Y. C., Qiao, G., Uskokovic, M., Xiang, W., Zheng, W., and Kong, J. (2004). Vitamin D: a negative endocrine regulator of the renin-angiotensin system and blood pressure. J. Steroid Biochem. Mol. Biol. 89-90, 387-392. doi:10.1016/j. jsbmb.2004.03.004

Li, Y., Li, Q., Zhang, N., and Liu, Z. (2020). Sunlight and vitamin D in the prevention of coronavirus disease (COVID-19) infection and mortality in the United States. Res Square. doi:10.21203/rs.3.rs-32499/v1

Liu, P. T., Stenger, S., Tang, D. H., and Modlin, R. L. (2007). Cutting edge: vitamin D-mediated human antimicrobial activity against Mycobacterium tuberculosis is dependent on the induction of cathelicidin. J. Immunol. 179, 2060-2063. doi:10.4049/jimmunol.179.4.2060

Malinovschi, A., Masoero, M., Bellocchia, M., Ciuffreda, A., Solidoro, P., Mattei, A., et al. (2014). Severe Vitamin D deficiency is associated with frequent exacerbations and hospitalization in COPD patients. Respir. Res. 15, 131-135. doi:10.1186/s12931-014-0131-0

Mangin, M., Sinha, R., and Fincher, K. (2014). Inflammation and vitamin D: the infection connection. Inflamm. Res. 63, 803-819. doi:10.1007/s00011-0140755-z

Manson, J. E., Cook, N. R., Lee, I. M., Christen, W., Bassuk, S. S., Mora, S., et al. (2019). Vitamin D supplements and prevention of cancer and cardiovascular disease. N. Engl. J. Med. 380, 33-44. doi:10.1056/NEJMoa1809944

Martineau, A. R., Jolliffe, D. A., Hooper, R. L., Greenberg, L., Aloia, J. F., Bergman, P., et al. (2017). Vitamin D supplementation to prevent acute respiratory tract infections: systematic review and meta-analysis of individual participant data. BMJ 356, i6583. doi:10.1136/bmj.i6583

Martínez-Moreno, J., Hernandez, J., and Urcuqui-Inchima, S. (2019). Effect of high doses of Vitamin D supplementation on dengue virus replication, toll-like receptor expression, and cytokine profiles on dendritic cells. Mol. Cell. Biochem. 464, 169-180. doi:10.1007/s11010-019-03658-w

Matthay, M. A., Ware, L. B., and Zimmermann, G. A. (2012). The acute respiratory distress syndrome. J. Clin. Invest. 122, 2731-2740. doi:10.1172/JCI60331

Meltzer, D. O., Best, T. J., Zhang, H., Vokes, T., Arora, V., and Solway, J. (2020). Association of vitamin D status and other clinical characteristics with COVID19 test results. JAMA Netw Open 3 (9), e2019722. doi:10.1001/ jamanetworkopen.2020.19722

Miroliaee, A. E., Salamzadeh, J., Shokouhi, S., and Sahraei, Z. (2018). The study of vitamin D administration effect on CRP and Interleukin-6 as prognostic biomarkers of ventilator associated pneumonia. J. Crit. Care 44, 300-305. doi:10.1016/j.jcrc.2017.08.040

Mora, J. R., Iwata, M., and Von Andrian, U. H. (2008). Vitamin effects on the immune system: vitamins A and D take centre stage. Nat. Rev. Immunol. 8, 685-698. doi:10.1038/nri2378

Mousavi, S., Bereswill, S., and Heimesaat, M. (2019). Immunomodulatory and antimicrobial effects of Vitamin C. Eur. J. Microbiol. Immunol. 9, 73-79. doi:10. 1556/1886.2019.00016

Nonnecke, B. J., McGill, J. L., Ridpath, J. F., Sacco, R. E., Lippolis, J. D., and Reinhardt, T. A. (2014). Acute phase response elicited by experimental bovine diarrhea virus (BVDV) infection is associated with decreased vitamin D and $\mathrm{E}$ status of vitamin-replete preruminant calves. J. Dairy Sci. 97, 5566. doi:10.3168/ jds.2014-8293

Nunnari, G., Fagone, P., Lazzara, F., Longo, A., Cambria, D., Di Stefano, G., et al. (2016). Vitamin $\mathrm{D}_{3}$ inhibits TNF alpha induced latent HIV reactivation in JLAT cells. Mol. Cell. Biochem. 418, 49-57. doi:10.1007/s11010-016-2732-z

Palacios, C., and Gonzalez, L. (2014). Is vitamin D deficiency a major global public health problem? J. Steroid Biochem. Mol. Biol. 144 (Pt A), 138-145. doi:10.1016/ j.jsbmb.2013.11.003

Parlak, E., Ertürk, A., Çağ, Y., Sebin, E., and Gümüşdere, M. (2015). The effect of inflammatory cytokines and the level of vitamin D on prognosis in CrimeanCongo hemorrhagic fever. Int. J. Clin. Exp. Med. 8, 18302-18310

Penna, G., and Adorini, L. (2000). 1 Alpha,25-dihydroxyvitamin D3 inhibits differentiation, maturation, activation, and survival of dendritic cells leading to impaired alloreactive T cell activation. J. Immunol. 164, 2405-2411. doi:10. 4049/jimmunol.164.5.2405

Pfeffer, P. E., and Hawrylowicz, C. M. (2012). Vitamin D and lung disease. Thorax 67, 1018-1020. doi:10.1136/thoraxjnl-2012-202139

Phokela, S. S., Peleg, S., Moya, F. R., and Alcorn, J. L. (2005). Regulation of human pulmonary surfactant protein gene expression by lalpha,25-dihydroxyvitamin
D3. Am. J. Physiol. Lung Cell Mol. Physiol. 289, L617-L626. doi:10.1152/ ajplung.00129.2004

Piemonti, L., Monti, P., Sironi, M., Fraticelli, P., Leone, B. E., Dal Cin, E., et al. (2000). Vitamin D3 affects differentiation, maturation, and function of human monocyte-derived dendritic cells. J. Immunol. 164, 4443-4451. doi:10.4049/ jimmunol.164.9.4443

Pilz, S., Marz, W., Cashman, K. D., Kiely, M. E., Whiting, S. J., Holick, M. F., et al. (2018). Rationale and plan for vitamin D food fortification: a review and guidance paper. Front. Endocrinol., 9. 373. doi:10.3389/fendo.2018.00373

Pludowski, P., Holick, M. F., Grant, W. B., Konstantynowicz, J., Mascarenhas, M. R., Haq, A., et al. (2018). Vitamin D supplementation guidelines. J. Steroid Biochem. Mol. Biol. 175, 125-135. doi:10.1016/j.jsbmb.2017.01.021

Qu, G., Li, X., and Jiang, G. (2020). An imperative need for research on the role of environmental factors in transmission of novel coronavirus (COVID-19). Environ. Sci. Technol. 12, 22-30. doi:10.1021/acs.est.0c01102

Raharusun, P., Priambada, S., Budiarti, C., Agung, E., and Budi, C. (2020). "Patterns of COVID-19 mortality and vitamin D: an Indonesian study," in SSRN electron. Available from:https://www.papers.ssrn.com/sol3/papers.cfm? abstract_id=3585561

Rehan, V. K., Torday, J. S., Peleg, S., Gennaro, L., Vouros, P., Padbury, J., et al. (2002). 1Alpha,25-dihydroxy-3-epi-vitamin D3, a natural metabolite of 1alpha,25-dihydroxy vitamin D3: production and biological activity studies in pulmonary alveolar type II cells. Mol. Genet. Metab. 76, 46-56. doi:10.1016/ s1096-7192(02)00022-7

Rezaei, R. (2018). Immunomodulatory effects of Vitamin D in influenza infection. Curr. Immunol. Rev. 14, 40-49. doi:10.2174/1573395513666171031162100

Rondanelli, M., Miccono, A., Lamburghini, S., Avanzato, I., Riva, A., Allegrini, P., et al. (2018). Self-care for common colds: the pivotal role of vitamin D, vitamin $\mathrm{C}$, zinc, and echinacea in three main immune interactive clusters (physical barriers, innate and adaptive immunity) involved during an episode of common colds-practical advice on dosages and on the time to take these nutrients/ botanicals in order to prevent or treat or treat common colds. Evid. Based Compl. Alt. Med. 2018, 1-36. doi:10.1155/2018/5813095

Sacco, R. E., Nonnecke, B. J., Palmer, M. V., Waters, W. R., Lippolis, J. D., and Reinhardt, T. A. (2012). Differential expression of cytokines in response to respiratory syncytial virus infection of calves with high or low circulating 25hydroxyvitamin $\mathrm{D}_{3}$. PLoS One 7, e33074. doi:10.1371/journal.pone.0033074

Sajadi, M. M., Habibzadeh, P., Vintzileos, A., Shokouhi, S., Miralles-Wilhelm, F., and Amoroso, A. (2020). Temperature, humidity and latitude analysis to predict potential spread and seasonality for COVID-19. Available at: https:// ssrn.com/abstract $=3550308$

Schwalfenberg, G. A. (2011). A review of critical role of Vit. D functioning of immune system and the clinical importance of Vit. D deficiency. Mol. Nutr. Food Res. 55, 96-108. doi:10.1002/mnfr.201000174

Scragg, R. (2020). The vitamin D assessment (ViDA) study - design and main findings. J. Steroid Biochem. Mol. Biol. 198, 105562. doi:10.1016/j.jsbmb.2019. 105562

Shirvani, A., Kalajian, T., Song, A., and Holick, M. (2019) Disassociation of Vitamin D's calcemic activity and non-calcemic genomic activity and individual responsiveness: a randomized controlled double-blind clinical trial. Sci. Rep. 9, 17685. doi:10.1038/s41598-019-53864-1

Sigmundsdottir, H., Pan, J., Debes, G. F., Alt, C., Habtezion, A., Soler, D., et al. (2007). DCs metabolize sunlight-induced vitamin D3 to 'program' T cell attraction to the epidermal chemokine CCL27. Nat. Immunol. 8, 285-293. doi:10.1038/ni1433

Steinstraesser, L., Tippler, B., Mertens, J., Lamme, E., Homann, H., Lehnhardt, M., et al. (2005). Inhibition of early steps in the lentiviral replication cycle by cathelicidin host defense peptides. Retrovirol 2, 2. doi:10.1186/17424690-2-2

Tan, C. W., Ho, L. P., Kalimuddin, S., Cherng, B. P. Z., Teh, Y. E., Thien, S. Y., et al. (2020). A cohort study to evaluate the effect of combination Vitamin D. Magnesium and Vitamin B12 (DMB) on progression to severe outcome in older COVID-19 patients. Med Rxiv Preprint. doi:10.1101/2020.06.01. 20112334

The Pharmacy Times (2020). The important role of vitamin D. Pharmacy Times. Available at: https://www.pharmacytimes.com/publications/issue/2010/february2010/ otcfocusvitamind-0210 
Tjabringa, G. S., Rabe, K. F., and Hiemstra, P. S. (2005). The human cathelicidin LL-37: a multifunctional peptide involved in infection and inflammation in the lung. Pulm. Pharmacol. Ther. 18, 321-327. doi:10.1016/j.pupt.2005.01.001

Umar, M., and Sastry, K. S. (2018). Chouchane AI. Role of vitamin D beyond the skeletal function: a review of the molecular and clinical studies. Int. J. Mol. Sci. 19. doi:10.3390/ijms 19061618

Van Herwegen, A.-S., Gysemans, C., and Mathieu, C. (2017). Vitamin D endocrinology on the cross-road between immunity and metabolism. Mol. Cell. Endocrinol. 453, 52-67. doi:10.1016/j.mce.2017.04.018

Van Schoor, N. M., and Lips, P. (2011). Worldwide vitamin D status. Best Pract. Res. Clin. Endocrinol. Metab. 25, 671-680. doi:10.1016/j.beem.2011.06.007

Veugelers, P. J., Pham, T. M., and Ekwaru, J. P. (2015) Optimal vitamin D supplementation doses that minimize the risk for both low high serum 25hydroxy vitamin $\mathrm{D}$ concentration in general population. Nutrients 7 , 10189-10208. doi:10.3390/nu7125527

Wang, D., Hu, B., Hu, C., Zhu, F., Liu, X., Zhang, J., et al. (2020). Clinical characteristics of 138 hospitalized patients with 2019 novel coronavirus-infected pneumonia in wuhan, China. J. Am. Med. Assoc. 323, 1061-1069. doi:10.1001/jama.2020.1585

Wimalawansa, S. J. (2020). Global epidemic of coronavirus-COVID-19: what we can do to minimize risks. Eur. J. Biomed. Pharm. Sci. 7, 432-438. Available at: https://www.ejbps.com/ejbps/abstract_id/6656

Wu, S.-E., and Miller, W. E. (2015). The human cytomegalovirus lytic cycle is induced by 1,25-dihydroxyvitamin $\mathrm{D}_{3}$ in peripheral blood monocytes and in the THP1 monocytic cell line. Virol 483, 8395. doi:10.1016/j.virol.2015.04.004

Xu, J., Yang, J., Chen, J., Luo, Q., Zhang, Q., and Zhang, H. (2017). Vitamin D alleviates lipopolysaccharide-induced acute lung injury via regulation of the reninangiotensin system. Mol. Med. Rep. 16, 7432-7438. doi:10.3892/mmr.2017.7546

Yang, I., Xu, J., and Zhang, H. (2016). Effects of vitamin D on ACE2 and vitamin D receptor expression in rats with LPS induced acute lung injury. Chin. J. Em. Med. 25, 1284-1289. doi:10.3760/cma.j.issn.1671-0282.2016.12.016
Zdrenghea, M. T., Makrinioti, H., Bagacean, C., Bush, A., Johnston, S. L., and Stanciu, L. A. (2017). Vitamin D modulation of innate immune responses to respiratory viral infections. Rev. Med. Virol. 27. doi:10.1002/rmv. 1909

Zhang, Z. R., Leung, W. N., Cheung, H. Y., and Chan, C. W. (2015). Osthole: a review on its bioactivities, pharmacological properties, and potential as alternative medicine. Evid. Based Compl. Alt. Med. 2015, 1-10. doi:10.1155/ 2015/919616

Zhao, Y., Ran, Z., Jiang, Q., Hu, N., Yu, B., Zhu, L., et al. (2019). Vitamin D alleviates rotavirus infection through a microrna-155-5p mediated regulation of the TBK1/IRF3 signaling pathway in vivo and in vitro. Int. J. Mol. Sci. 20, 3562. doi:10.3390/ijms20143562

Zhou, F., Yu, T., Du, R., Fan, G., Liu, Y., Liu, Z., et al. (2020). Clinical course and risk factors for mortality of adult inpatients with COVID-19 in Wuhan, China: a retrospective cohort study. Lancet 395, 1054-1062. doi:10.1016/S01406736(20)30566-3

Conflict of Interest: UD was employed by the company UND Life Sciences LLC.

The remaining authors declare that the research was conducted in the absence of any commercial or financial relationships that could be constructed as a potential conflict of interest.

Copyright (c) 2020 Boulkrane, Ilina, Melchakov, Fedotova, Drago, Gozzo, Das, Abd El-Aty and Baranenko. This is an open-access article distributed under the terms of the Creative Commons Attribution License (CC BY). The use, distribution or reproduction in other forums is permitted, provided the original author(s) and the copyright owner(s) are credited and that the original publication in this journal is cited, in accordance with accepted academic practice. No use, distribution or reproduction is permitted which does not comply with these terms. 